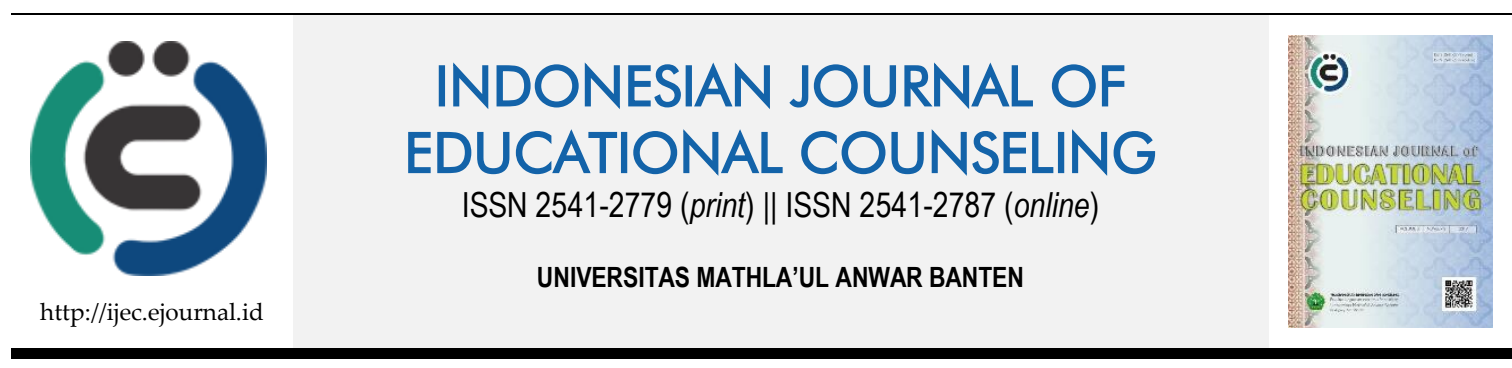

Theoretical/Conceptual Article

\title{
Pedagogy of Peacefulness as an Effort of Peaceful Education at School
}

\author{
Eva Imania Eliasa ${ }^{1,2}$, Sunaryo Kartadinata ${ }^{2}$, Ilfiandra², Juntika Nurihsan ${ }^{2}$ \\ ${ }^{1}$ Universitas Negeri Yogyakarta, ${ }^{2}$ Universitas Pendidikan Indonesia
}

\begin{tabular}{|c|c|}
\hline Article History & ABSTRACT \\
\hline $\begin{array}{l}\text { Received: } 09.01 .2019 \\
\text { Received in revised form: } \\
\text { 20.03.2019 } \\
\text { Accepted: } 02.07 .2019 \\
\text { Available online: } 23.07 .2019\end{array}$ & $\begin{array}{l}\text { Based on the phenomenon occurred at all level of education, it was found that } \\
\text { the circumstances of the schools were unsafe and uncomfortable for students } \\
\text { and academics. There were a number of direct and indirect violence carried out } \\
\text { at schools and it had impacts on physical and psychological health of students. } \\
\text { There was no existence of positive peace in the form of structural violence, } \\
\text { socio-cultural violence, ecological violence and negative peace such as tribal } \\
\text { warfare, fights and aggression. What happened actually although the nature of } \\
\text { man in conscience had the basic harmony and desire to live together in } \\
\text { tranquility? Therefore, the common perception of the concept of peace and } \\
\text { peace pedagogy was needed to be created. Teachers as peace educators, thus, } \\
\text { played an important role as a figure that had the personality of peace in the } \\
\text { classroom and at school. The teacher as a peaceful personality consisted of three } \\
\text { components: peaceful states, attitudes, and behavior that were consistent across } \\
\text { one's life spaces and life span. Moreover, the school also needed to develop an } \\
\text { educational approach in the curriculum in synergy with the goals of education. }\end{array}$ \\
\hline & KEYWORDS: Negative Peace, Peace, Peaceful Personality, Positive Peace. \\
\hline
\end{tabular}

DOI: $10.30653 / 001.201932 .99$

This is an open access article distributed under the terms of the Creative Commons Attribution 4.0 International License, which permits unrestricted use, distribution, and reproduction in any medium, provided the original work is properly cited. (c) 2019 Eva Imania Eliasa, Sunaryo Kartadinata, Ilfiandra.

\section{INTRODUCTION}

Based on the result of research in the academic year of $2005-2006$, about $38 \%$ of elementary schools in Romania had, at least, one violence, with an average of about 29 crimes per 1.000 students (Gerstein, Lindsey, Alisha, \& Akpan, 2014). Other data say that more than $60 \%$ of children experienced direct or indirect violence at school (Finkelhor, Turner, Ormrod, \& Hamby, 2009) and about 1.5 million fatal crimes had been committed against students each year at school (CDC, 2008; Gerstein, Lindsey, Alisha, \& Akpan, 2014). Many of the nonfatal crimes were from bullying, in which about one third of the students was reported of being bullied during the school year (DOE, 2008). The survey results of eighth graders about bullying reported that " $67 \%$ of bullying is sometimes fun 
to do, $20 \%$ is not a problem with bullying, and $23 \%$ is reported that they feel good when they hit someone" (Virginia Youth Violence Project, as cited in Dinkes, Kemp, \& Baum, 2009). Similarly, when being asked about aggressive behavior, $59 \%$ of the eighth graders were annoyed, $56 \%$ of the seventh grade students saw that aggressiveness leads to fights, and $46 \%$ of sixth grade students reported that they felt offended on how the aggressor doing their action.

Crimes are also committed by adolescent students, when they are both inside and outside school. This crime was found the most commonly during the transitional period, i.e. before and after school, at lunch, and at the beginning of each semester (Anderson et. al., 2001; CDC, 2001).The aggressors of crime are such as fights inside and outside school, property vandalism, skipping school, and dropping out as a result of their anger, anxiety, and depression (Chan, Fung, \& Gerstein, 2013; Fung, Gerstein, Chan, \& Engebretson, 2015) and the lack of empathy towards others (Fung, Gerstein, Chan, \& Engebretson, 2015).

The phenomenon above is so worrying and needs to be considered. Students do not feel peaceful and comfortable at school. The presence of bullying, aggressive minor behavior (i.e. teasing, mocking, harassing) can reduce the student's learning concentration at school and interfere the learning activities. Furthermore, this incident resulted in the weakening of school climate, because for the victims, violence in schools caused visible and invisible injuries that could lead to various negative health outcomes (CDC, 2010). Students who feel insecure and unsafe at school, when they are on their way to and from school, have shown that they have spent the day in a saturated state, wanted to leave early, and had an experience of depression and anxiety (CDC, 2010).

Similarly there is a negative tendency that occurs in people around the world. Negative trends in social environments are such as high rates of crime, violence, drug abuse and behavioral problems of children in schools and colleges (Das \& Das, 2014). The quality of tolerance, trust, empathy, solidarity of cooperation is found less among children now.

Therefore, from some of the above phenomena, there are several things to be asked, namely: a) What is the nature of human about peace?; b) What is the concept of peace? c) What is the concept of pedagogy of peace?; d) How is the personality of peace?; and e) How is the realization of the pedagogy of peace in school?

\section{LITERATURE REVIEW}

\section{Human's Nature About Peace}

Some answers to the question, what is the nature of human about peace? Presented from several perspectives, including: QS. Al Maidah: 32.

"We therefore set up one law for the Bani Israel, that: He who kills a man, not because that person kills another person or not for causing damage on earth, is as if he has killed all human. And whoever preserves the life of a man, it is as if he has preserved all life. And indeed had come to them Our messengers with clear information, then many of them afterwards sunguh really crossed the line in doing damage on earth."

Being clearly illustrated that, every human being is a brother, if your relatives feel sick, it will also hurt other's human body. Deep empathy is formed indirectly and brings 
closeness, maintains closeness and harmony with fellow human beings. But, if there are human beings who have killed others, in fact he has killed all human beings and makes damage on earth.

The same passage is also explained in QS. Al-Baqarah: 190, "Fight in the way of Allah for those who fight you, but do not transgress, for Allah actually does not love those who transgress."

From the above verse, in fact human beings by nature have a sense of togetherness with each other, maintain their life together. However, if there are other human beings do violence, treat well, do not fight and do not exceed the limit.

Similarly, the Dalai Lama's teachings (1999; Castro, 2008) also emphasize that: 1) Human nature is basically gentle and not aggressive; 2) Inner peace is the principal characteristic of happiness; and 3) Negative thoughts and feeling cause unhappiness and suffering

Hinduism (Castro, 2008) also teaches: 1) Practice Ahimsa (Non-violence or NonInjury); and 2) Promote love and compassion as well as justice.

As for some identifiable custom and tradition give philosophies of peace in it, including: 1) Tribes in Indonesia: Javanese tribes with "Tata Tengtrem Kertaraharja", Sundanese tribe with "Cageur, Bageur, Tentrem", also tribes of Batak, Baduy, Bali, Bugis with their own slogan in it about peace and harmony in the community; 2) Maori (New Zealand); and 3) Mindanau (Philippines) with one of his proverbs: "The Land is both our father and mother - If you break something, you repair it - If you make something sick, you must heal him/ her, asking forgiveness is not enough" (Castro, 2008)

Most Africans also have developed rich cultural traditions to preserve harmony, and maintain peace with the cultivation of group solidarity (Murithi, 2012). It is referred to as 'Ubuntu' in many parts of Africa, especially among the Bantu Timur, Tengah and South Africa languages, and, 'a culture of world view that seeks to capture the essence of what it means to be human'.

The Taoist and Tantric cultures have the principle of freeing the mind from the game of the intellect, and the destructive illusion of peace (Dietrich, 2012). They use human strength physically and psychical, intellectual and spiritual capacity to experience the connection between the mind and the outer world of the body and the cosmos. The metaphysical tantric, in the Hindu or Buddhist tradition, unifies all duality or polarity. It is assumed that the universe is formed by active and passive polarity, women and men, Shakti and Shiva. The energy that flows between them is alive.

Basically, humans live in unity and human principles have the ability to bring a peace strategy (Galtung, 1969). Therefore, the nature of human beings about peace is in their respective conscience (Hidayat, 2017). There is equality of principle of peace within each human being from any part of the world and from various teachings and cultures wherever they are. 


\section{Concepts of Peace}

William James is a peace psychologist who explains that the terminology of peace is a new dictionary in psychology, and in the early twentieth century, most of the theory and practice of psychology were dominated by Western perspectives which were about peace research and gave preferences to the problem of aggression and direct forms of violence (Buss, 1961; Berkowitz, 1962; Bandura, 1973; Deutsch, 1995). However, since the end of the Cold War in the late 1980s, the trend of the word "peace" in the field of psychology has grown exponentially (Christie, 2014). This suggests that broader context considerations begin to be explored. In the last few decades, peace psychology has also become internationalized and contextual (Bretherton \& Balvin, 2012; Hamber, 2009; Montero \& Sonn 2009; Montiel \& Noor, 2009; Breterthen, 2015).

Johan Galtung is a figure and researcher on the concept of peace from Norway. According to Galtung (1969), peace is the absence/ reduction of violence of all kinds. Peace is nonviolent and creative conflict transformation. There is positive and negative peace (Galtung, 1969). Peace refers to both direct and indirect violence. Direct violence is understood as a physical aggression that can cause physical damage to death. Indirect violence consists of structural and cultural factors. Structural violence presents in socially unfair societies (i.e. health gaps) while the masks of cultural violence or validation of structural violence (i.e. indifference or support from domestic violence (Cremin, Sellman, \& McCluskey, 2012, p. 430).

Positive peace requires problem solving of structural and cultural violence, while negative peace is achieved by removing the threat of direct violence (Cremin, 2016). Negative peace is achieved through peace initiatives, but positive peace is achieved through peace-making and peace-building. Negative peace is described as a situation in the absence of other forms of abuse or in other words the definition is the same as the definition in the dictionary of peace. A dictionary of peace is "A State of Quiet, Freedom from Contention, Ease of Mind or Conscience, Tranquility, Quiet, Stillness and Silence" meaning quite comprehensive and each of the particular individual meanings deserves detailed discussion and explanation. Peace does not only mean no existence of war or conflict. It has something to do with people's objections and attitudes. In the deepest sense, peace is a sense of goodwill towards others, wishing them the best in life. There is love and caring for others, not just as human beings, but as brothers and sisters whose happiness and well-being directly affect a person. Thus, peace is a dynamic concept because it relates to humans who have recurrent, contextual, varied and urgency needs. Democracy, freedom, and equality for all are not enough, as social justice and inequality should be also understood and noticed. Human rights and responsibility must be respected. In a peaceful society, people will work together to resolve conflicts, develop morals, treat each other with justice, fulfill basic needs and respect for one another. Basically, people will live in unity.

Terms that often appear in peace and peace research are Peace-making and Peace building. Peace making occurs when conflicts occur, and peace occurs when there is a need to proactively reduce the likelihood of conflict. Then, Peace-building is easier to implement than to make peace, and peace building is the most difficult of all because it requires political will to bring social. According to Hugo Grotius in 1624, it has been mentioned that peace as merely the absence of war or direct violence (Castro, 2008). Similarly, the opinion of Anderson (2004), peace as a condition in which individuals, 
families, groups, communities, and/or nations experience low levels of violence and engage in mutually harmonious relationships (Sims, 2014). Peace is a global concept and every individual must be filled with peace for physical and mental health (Das \& Das, 2014). This is the value of life (living value) that must be valued from birth to death. From the previous explanation, the concept of peace can be explained in the Picture 1 .

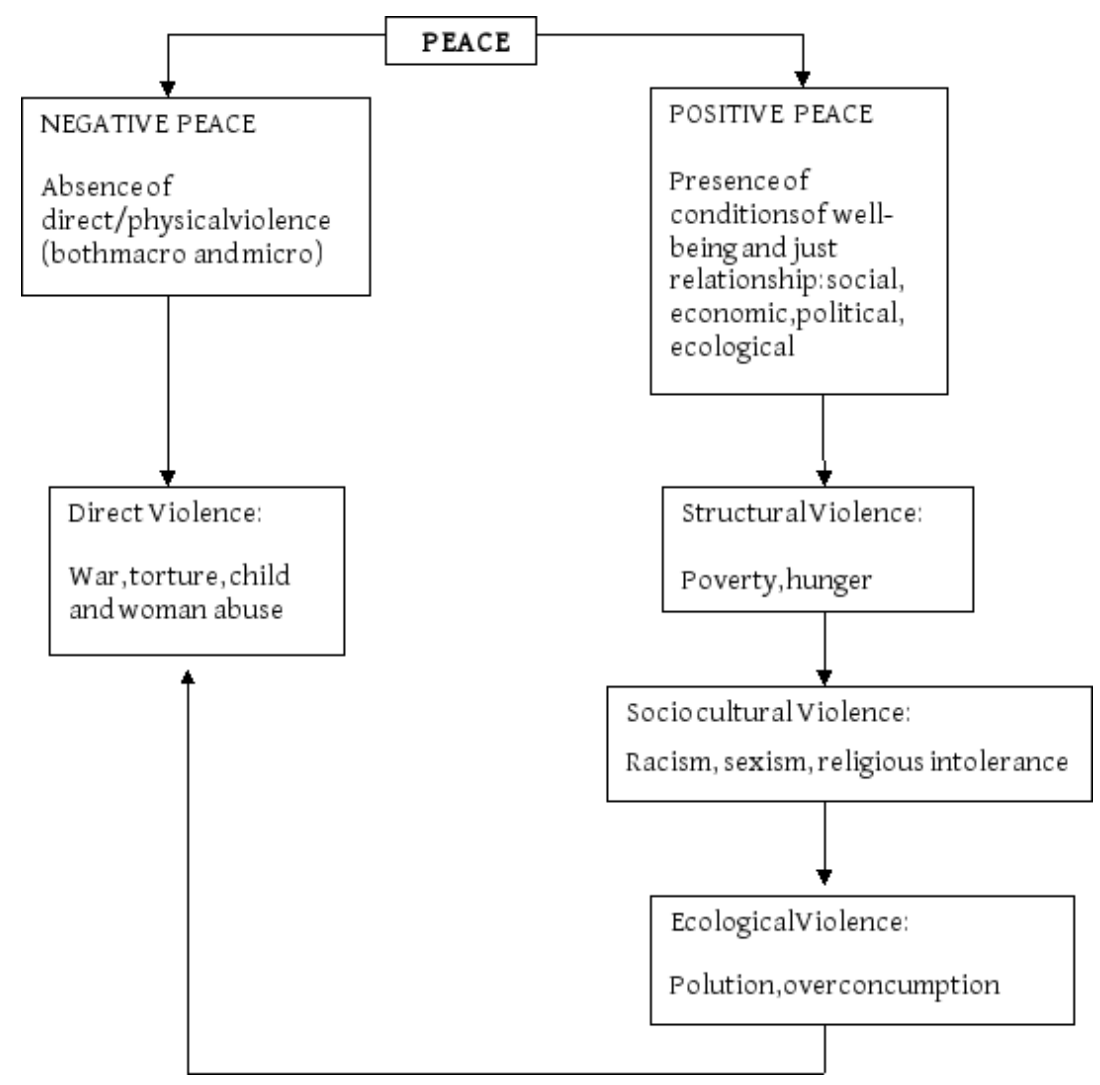

Picture 1. Scheme of Peace Concept

(Source: Castro, 2008)

Violence is seen from three points of view, from the violent triangle, illustrating that all kinds of violence breed each other in many ways and the violence reproduces itself in all dimensions. Related to cultural violence, Galtung (1969) claims it can be contained in all spheres of social life (religion, law, ideology, science, etc.)

In the 1960s, there was a peaceful discourse, initially functioning as a prevention of violence, conflict resolution, nuclear threat, and the improvement of democracy and structural violence. But in the last decade, when the focus of peace discourse focuses more on group handling, then individual peace seems to be neglected. Thus, the effort to introduce the concept of self-peace continues on the level of manifestation and psychology, so that a special study of personal peacefulness and peaceful personality is developing (Sims, Nelson, \& Puopolo, 2014). 


\section{Pedagogy of Peacefulness}

UNESCO (2001) affirms that peace education is an attempt to respond to problems of conflict and violence on scales ranging from the global and national to the local and personal. It is about exploring ways of creating more just and sustainable futures. Further, it is explained that peace education is holistic. Fran Schmidt and Alice Friedman (UNESCO, 2001) explain that peace education encompasses the physical, emotional, intellectual, and social growth of children in a framework rooted in traditional human values. It is based on the philosophy that teaches love, affection, trust, justice, cooperation and respect for the human family and all life on our beautiful planet.

Peace education is a broad discipline and has been defined in various ways. There is no universally accepted definition. Generally, peace education is aimed at teaching the information, attitudes, values and behavioral competencies required for nonviolent conflict resolution and for building and maintaining mutuality, harmony. UNICEF has defined peace education as "the process of promoting the knowledge, skills, attitudes and values needed to bring the behavioral change that will enable children, youth and adults to prevent conflict and violence, culturally and structurally; also to resolve the conflict peacefully, and to create conducive conditions to peace, both intrapersonal, interpersonal, intergroup (social), national or international scale" (Das \& Das, 2014).

Peace education has a different kind as peace educators seek to overcome various forms of violence in different social contexts. In 1950, as a matter of concern, after the bombing incident in Hiroshima and Nagasaki, teachers in Japan led a campaign for peace education known as 'A bomb Education'. In Southern countries where high levels of cause of poverty and violence, peace education is often referred to as 'Development Education', in which students learn about different strategies to address the problem of structural violence. In Ireland, peace education is referred to as 'education for mutual understanding' as Catholics and Protestant efforts use educational strategies to undo centuries of hostility (Smith \& Robinson, 1992). Likewise, in South Korean, peace education is referred to as 'Reunification Education' (Synott, 2002). Peace education responds to various forms of conflict and violence (direct, structural, and cultural) and creates new forms of educational praxis in social contexts around the world (Galtung 1995).

\section{Peace Personality}

The individual characteristics of peace love or anti-violence according to Gandhi (1969), i.e. anti-physical violence, anti-psychological violence, empathy, persistent search for truth (satyagraha), and willing to sacrifice (tapasya) (Castro, 2008). The peacefulness of heart within the individual is the core domain of the support of interpersonal interaction structure. The peacefulness of one's social relationships is largely determined by the individual's peacefulness of himself, and the relationship of influence between them is reciprocal (Sims, Nelson \& Puopolo, 2014).

According Brantmeier (2013) Peace Behavior or peaceful behavior is defined here as an act that creates and maintains a non-violent and harmonious relationship. Cooperation and kindness are peaceful examples of behavior. Peaceful conditions include emotions in it such as happiness, tranquility, comfort and security as well as the condition of inner harmony between self-aspirations. Peace behavior is defined here as beliefs and values that facilitate the creation and maintenance of relationships in the absence of violence and 
harmony. Thus, a peaceful personality connotes consistent peaceful behavior and attitude over time and across relevant contextual domains. Relevant domains are where peaceful behavior, peaceful attitude can occur in various relationships within individuals, between groups, and between individuals and others, groups, and entities. All these relationships have the potential for conflict, violence, and harmony. Anderson (2001) identifies seven specific contexts in which the conditions of peace can be experienced. This context is in individuals (intrapersonal peace), between individuals (interpersonal peace), between social groups (social peace), in society (civil peace), in the nation (national peace), between countries (international peace), and with nature (ecological peace). In parallel with the opinions of Sims, Nelson \& Puopolo (2014), the domain of human relationships consists of seven special contexts, namely individuals (intrapersonal), interpersonal, social, and the universe (ecological).

Each of these contexts can be seen as domains in which individuals can behave peacefully, withstand peaceful attitudes, and/ or experience peaceful conditions. All of these domains are relevant with the constructs of having a peaceful personality because they represent the context of important relationships with other individuals. More details can be seen from the Picture 2 .

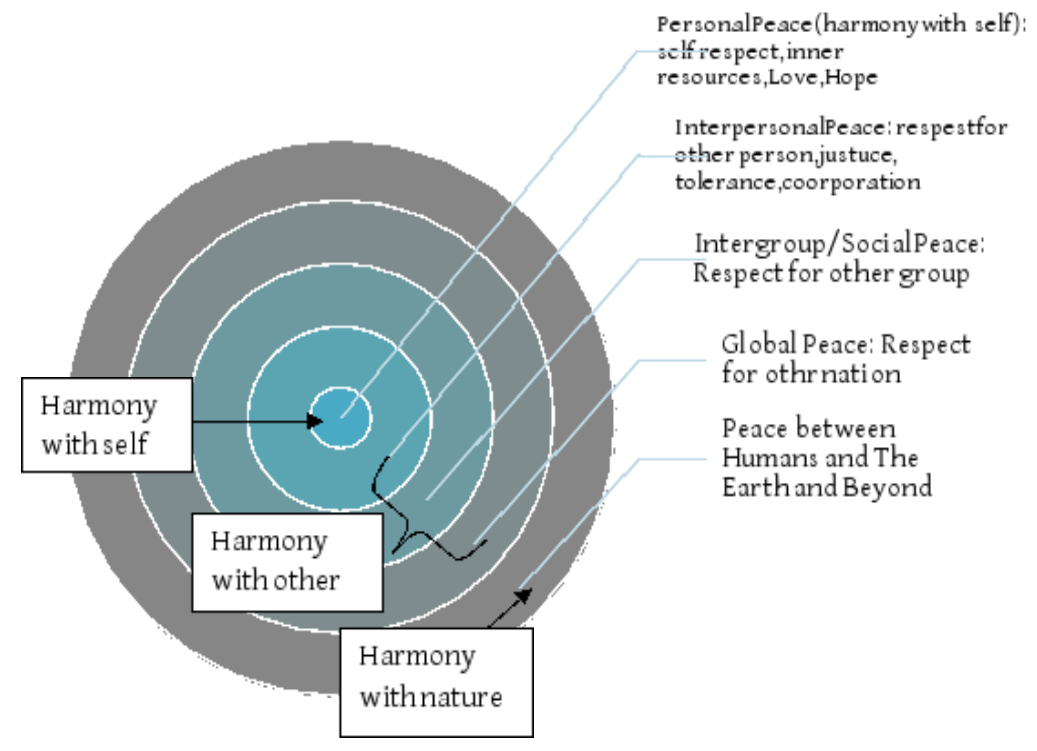

Figure 2. Level of Peace

An effort to judge whether a person is a "peaceful person" can be achieved in various ways. One method has been applied and replicated utilizing Teenagers without Violence Test (TNT) (Browne et.al. 2010; Mayton, 2009). TNT is a reliable and valid instrument based on the philosophy and writings of Mohandas Gandhi (1951), and assesses five subscales of non- physical-violence, non-psychological-violence, empathic, satyagraha and tapasya (Mayton 2009; Mayton, 2014).

\section{DISCUSSION}

Education by adopting a peace education approach brings hope that internal and external conflicts will alter the 'hearts and minds' of both sides (Solomon and Cairn, 2010). Peace education becomes mediation and narration that is considered useful to achieve 
mutual understanding and reduce conflict tension (Maoz, 2010). However, as shown in various studies, the role of education in the situation of conflict and peace and its effectiveness are mediated by several factors. For example, the nature of conflict and continuity from the past to the present affects the methods used and the opportunities for successful education for coexistence and peace (Bar-Tal 1998, 2004; Bar-Tal and Rosen 2009; Yogev, 2010, 2012). Similarly, while there are many values of peace education in a state of prolonged conflict, it is questionable whether the peace process in the education movement is crucial to the success of the program (Bar-Tal, Rosen, and Nets-Zehngut, 2010). Evidently, teaching about peace or conflict embedded in certain contexts in an environment that is not conducive, simply becomes a hope at schools to be an educational promotion and contributes to a change of unbalanced reality (Salomon and Cairns 2010). Therefore, there remains an element of ordering and explaining the role of schools, the mission of 'bringing peace' (Maoz 2010).

How important is the application of peace education in schools, in which teachercentered in it is as a figure and profile of peace educators. Teachers and headmasters participate in determining the success of peace education at school. Peace educators must have a peace competency that can be an example for learners. In line with the opinion of Sims (2014), a peaceful personality consists of three components: peaceful states, attitudes, and behaviors that are consistent across one's life spaces and life span.

Peace educators as a model of peaceful behavior have the following abilities: 1) As actions that create and maintain nonviolent and harmonious relationships, cooperation and kindness; 2) Peaceful states include emotions such as calmness, serenity, and security as well as conditions of harmony between aspects of self;3) Peaceful attitudes are defined here as beliefs and values that facilitate the creation and maintenance of nonviolent and harmonious relationships; and 4) Peaceful personality connotes consistently peaceful behavior, states, and attitudes over time and the relevant contextual domains. (Castro, 2008).

As for, Betty Reardon (1988) asserts about peace educators: 1) Having global responsibility, civilizing peace intensively, being full of vision, having optimistic spirit \& builder of positive thinking, and believing that education can be a tool of constructive change; 2) Being motivated in service, engaging in social community; 3) Long life learner: constantly renewing the learning capacity and updating it with the outside world; 4) Functioning as a transmitter and transformer (critical and reflexive) culture; 5) Always having a sense of community: maintaining mutualism relationships, guardianship of peace and human dignity; and 6) Being gender-sensitive: build positive self-identification of learners, develop gender sensitivity and responsibility in others. Below is a scheme of peace educator competence.

\begin{tabular}{|c|c|c|}
\hline $\begin{array}{l}\text { Knowledge: } \\
\text { 1. Holistic concept of } \\
\text { peace } \\
\text { 2. Conflict \& violence } \\
\text { 3. Some peaceful } \\
\text { alternative }\end{array}$ & $\begin{array}{l}\text { Skills: } \\
\text { 1. Reflection } \\
\text { 2. Critical thinking } \\
\text { 3. Decision making } \\
\text { 4. Imagination } \\
\text { 5. Empathy } \\
\text { 6. Conflict resolution } \\
\text { 7. Communication } \\
\text { 8. Group building }\end{array}$ & $\begin{array}{l}\text { Attitude/Values: } \\
\text { 1. Self-respect } \\
\text { 2. Respect for others } \\
\text { 3. Gender } \\
\text { 4. Global concern } \\
\text { 5. Ecological concern } \\
\text { 6. Justice } \\
\text { 7. Social responsibility }\end{array}$ \\
\hline
\end{tabular}

Picture 3. Scheme of Knowledge, Skills, and Attitude as Peace Educator Competence 
And according to Brantmeier (2011), there are several activities that must be done by peace educators at schools: 1) Raising consciousness through dialogue; 2) Imagining nonviolent alternatives; 3) Providing specific modes of empowerment; 4) Transformative action; and 5) Reflection and re-engagement.

Mayton (2014) explains that the peaceful personality is a combination of four components (model of diamond) or non-violent level, i.e. intrapersonal, interpersonal, social and world violence. Then, Castro (2008) initiated a peaceful class or creating a peaceable classroom by using the following steps: 1) Declaration of the Peace Zone; 2) Start from the teacher; 3) Affirm the students; 4 Express the feelings; 5) Build respect and accept differences; 6) Work cooperatively rather than competition activity; 7) Teach conflict resolution peacefully and constructively; 8) Practice the students' communication skills; and 9) Use positive sentences, change negative statements

The process of applying pedagogic peace at school needs wholeness. This is because many messages and values of peace are consistent and need to be maintained in strengthening educational goals. The involvement of school roles in this approach encompasses various domains; school environment areas (learners, teachers, and staff) and community outside the school, covering various aspects: the process of teaching and learning activities, methods, student activities, administrative policies, school structures and relationships. The school of peace must be a counter to the dominant paradigm and capable of being the initiator of the transformation process. Therefore, schools must take responsibility for maintaining this quality in students and idealized education means for this. Peace education should be delivered in every educational institution through different curriculum and co-curricular. Each educational institution provides an opportunity for students to participate in different curricular activities. Therefore, this cocurricular activity should be used as a vehicle to develop the values of peace in the minds of the students so that they can be preserved in the peace of the loving person.

\section{CONCLUSION}

The process of implementing peace pedagogy in schools is needed wholeness. This is because many messages and values of peace are consistent and need to be maintained in strengthening educational goals. The involvement of school roles in this approach includes various domains; areas of the school environment, school members (students, teachers, and staff) and communities outside the school, covering various aspects: the process of teaching and learning activities, methods, student activities, administrative policies, structures \& school relations. Peace schools must be a match against the dominant paradigm and be able to be the initiator of the transformation process. Therefore, schools must take the responsibility of maintaining this quality in students and the ideal peace education for this. Peace education must be delivered at each educational institution through different curricula and curricula. Each educational institution provides opportunities for students to participate in different curricular activities. Therefore this co-curricular activity must be used as a vehicle to develop the values of peace in the minds of students so that they can be nurtured in the peace of a loving person. 


\section{REFERENCES}

Al-Qur'an

Anderson, M., Kaufman, J., Simon, T. R., Barrios, L., Paulozzi, L., Ryan, G. Feucht, T. (2001). School-associated violent deaths in the United States, 1994-1999. Journal of the American Medical Association, 286(21), 2695-2702.

Bandura, A. (1973). Aggression: A social learning analysis. Englewood Cliffs: Prentice-Hall.

Bar-Tal, D., \& Y. Rosen. (2009). Peace Education in Societies Involved in Intractable Conflicts: Direct and Indirect Models. Review of Educational Research 79(2): 557-575.

Bar-Tal, D., Y. Rosen, \& Z. R. Nets. (2010). Peace education in societies involved in intractable conflicts: goals, conditions, and directions. In G. Salomon and E. Cairns (Eds.), Handbook of Peace Education (pp. 21-43). New York: Psychology Press.

Berkowitz, L. (1962). Aggression: A social psychological analysis. New York: McGraw-Hill.

Brantmeier, E. J. (2013). Toward a critical peace education for sustainability. Journal of Peace Education, 10(3), 242-258.

Bretherten, D. (2015). Methodologies in peace psychology: peace research by peaceful means. USA: Springer.

Bretherton, D., \& Balvin, N. (2012). Peace psychology in Australia (Peace Psychology Book Series). New York: Springer.

Browne, C. N., Lloyd, J. B., Konkright, R. F., Toney, B. R., Severson, H. E., \& Mayton, D. M. (2010). Inner peace: Personality characteristics of a peaceful person. San Diego, CA: The American Psychological Association.

Buss, A. H. (1961). The psychology of aggression. New York: Wiley.

Castro, G. (2008) Peace education: A pathway to a culture of peace. Philippines: Center for Peace Education.

Centers for Disease Control and Prevention [CDC]. (2001). Temporal variations in school as sociated student homicide and suicide events - United States, 1992 -1999. Morbidity and Mortality Weekly Report, 50(31), 657-660.

Centers for Disease Control and Prevention [CDC]. (2008). Youth Risk Behavior Surveillance-United States, 2007. Surveillance Summaries, June 6, 2008. Morbidity and Mortality Weekly Report, 57(4), 1-131.

Centers for Disease Control and Prevention [CDC]. (2010). Understanding School Violence: Fact Sheet 2010. Retrieved from www.cdc.gov/ncipc/dvp/YVP/SV_factsheet.pdf.

Chan, J. Y., Fung, A. L., \& Gerstein, L. H. (2013). Correlates of pure and co-occurring proactive and reactive aggressors in Hong Kong. Psychology in the Schools, 50(2), 181192. 
Christie, D. J. (2014). Global developments in the science and practice of peace psychology. In S. Cooper and K. Ratele (Eds.), Psychology serving humanity Vol. 2 (pp.28-46). New York: Psychology Press.

Cremin, H., Sellman, E., \& McCluskey, G. (2012). Interdisciplinary perspectives on restorative justice: Developing insights for education. British Journal of Educational Studies, 60(4), 421-437.

Cremin, H. (2016). Peace education research in the twenty-first century: three concepts facing crisis or opportunity?. Journal of Peace Education, 13(1), 1-17.

Danesh, H. B. (2008). The education for peace integrative curriculum: Concepts, contents and efficacy. Journal of Peace Education, 5(2), 157-173.

Das, S., \& Das, K. K. (2014). Imparting peace education through coscholastic activities at the school level. European Scientific Journal, 1, 319-326.

Department of Education [DoE]. (2008). Indicators of school crime and safety: 2008 (NCES 2009-022). Dept. of Education and Justice (US). Washington, DC: US Government Printing Office.

Deutsch, M. (1995). William James: The first peace psychologist. Peace and Conflict, 1(1), 2735.

Dietrich, W. (2012). Many peace: Interpretations of peace in history and culture. New York: Palgrave Macmillan.

Dinkes, R., Kemp, J., \& Baum, K. (2009). Indicators of school crime and safety: 2009. NCES 2010-012/NCJ 228478. US: National Center for Education Statistics of Institute of Education Sciences, US.

Finkelhor, D., Turner, H., Ormrod, R., \& Hamby, S. L. (2009). Violence, abuse, and crime exposure in a national sample of children and youth. Pediatrics, 124(5), 1411-1423. doi: 10.1542/peds.2009-0467.

Fung, A. L., Gerstein, L. H., Chan, Y., \& Engebretson, J. (2015). Relationship of aggression to anxiety, depression, anger, and empathy in Hong Kong. Journal of Child and Family Studies, 24(3), 821-831.

Galtung, J. (1969) Violence, peace, and peace research. Journal of Peace Research, 6(3), 167191.

Galtung, J. (1995). Violence, Peace and Peace Research. In M. Sall (Ed.), Essay on peace. Brisbane: University of Queensland Press.

Gandhi, M. K. (1951). Non-violent resistance. New York: Schocken Books.

Gerstein, L., Lindsey, B. L. O. M., Alisha, S. I. N. K., \& Akpan, A. (2014). Implementing sport for peace principles with elementary school student leaders. Revista de Cercetare si Interventie Sociala, 45, 7-16. 
Hidayat, A. (2017). Peaceful in pesantren: The involvement of santri's peaceful environment and personality. Al-Ta lim Journal, 24(2), 79-92.

Maoz, I. (2000). An Experiment in Peace: Reconciliation- Aimed Workshops of JewishIsraeli and Palestinian Youth. Journal of Peace Research, 37(6), 721-736.

Mayton, D. M. (2009). Non-violence and peace psychology: Intrapersonal, interpersonal, societal, and world peace. New York: Springer.

Mayton, D. M. (2014). Peacefulness as nonviolent dispositions. In G. K. Sims, L. L. Nelson, and M. R. Puopolo (Eds.), Personal peacefulness: Psychological perspectives Vol. 20 (pp. 45-70). New York: Springer.

Montero, M., \& Sonn, C. (2009). Psychology of liberation: Theory and applications (Peace Psychology Book Series). New York: Springer.

Montiel, C. J., \& Noor, N. M. (2009). Peace psychology in Asia (Peace Psychology Book Series). New York: Springer.

Murithi, T. (2012). Peacemaking and African Traditions of Justice and Reconciliation. In S. A. Nan, Z. C. Mamphilly, and A.Barloti (Eds.), Peacemaking: From practice to theory (pp. 275-294). Oxford: Praeger.

Nets-Zehngut, R., \& Bar-Tal, D. (2007). The intractable Israeli-Palestinian conflict and possible pathways to peace. In J. Kuriansky (Ed.), Beyond bullets and bombs: Grassroots peace building between Palestinians and Israelis (pp. 3-13). Westport, CT: Praeger.

Reardon, B. (1988). Comprehensive peace education: educating for global responsibility. New York, Teachers College Press.

Salomon, G. (2002). The nature of peace education: Not all programs are created equal. In G. Salomon and B. Nevo (Eds.), Peace education: The concepts, principles, and practices around the world. Mahwah, NJ: Lawrence Erlbaum Associates.

Salomon, G., \& Cairns, E. (Eds.). (2010). Handbook on peace education. New York: Psychology Press.

Sims, G. (2014). Personal Peacefulness: Psychological perspective (Peace psychological book series). USA: Springer.

Smith, A., \& Robinson, A. (1992). Education for mutual understanding: perceptions and policy. Coleraine: University of Ulster Center for the Study of Conflict.

Synott, J. (2002). The teachers' movement struggle for a model of reunification education in South Korea. Social Alternatives, 21(1), 42-48.

UNESCO. (2001). Learning the way of peace. Paris: UNESCO.

Yogev, E. (2010). A crossroads: History textbooks and curricula in Israel. Journal of Peace Education, 7(1), 1-14. 